\title{
Private Security in Ethiopia: Key Challenges and the Ways Forward
}

\author{
Abera Tsegaye Eshete \\ Ethiopian Police University, PO box 1503, Sendafa, Ethiopia
}

\begin{abstract}
This study sought to explore private security in Ethiopia focusing on the challenges that hindered it to provide effective security service to its clients. To this end, the study employed a qualitative research method. Data were generated from both primary and secondary sources using in-depth interviews, focus group discussion, observation, and document review. Primary data were purposively gathered from lawmakers, security service providers, law enforcement organs, and private security service users. They are identified as the major actors that have a direct relevance to the subject under investigation. Secondary data were consulted from pertinent legislations and other materials. Thematic analysis was used to analyze the data. The study found that the major challenges as regards private security are lack of comprehensive legal and policy frameworks, absence of institutional arrangements, lack of standardized training and education. Given these, the researcher, among other things, suggested strong normative frameworks, institutional arrangements, standardized training along with periodic evaluations.
\end{abstract}

Keywords: Private Security, Private Security Service, Challenges, Training

DOI: $10.7176 / \mathrm{JAAS} / 75-02$

Publication date:August $31^{\text {st }} 2021$

\section{Introduction}

The private security (PSC) industry is becoming one of the key players in the security arena. It plays a significant role in guaranteeing and maintaining peace and security of the public at various levels. Nowadays, private security personnel are in the process of outnumbering the police. As Lemon (2018:4) states, "in the private security industry more than a million officers contribute daily to crime prevention and reduction". They have played a great role in providing a partial solution to the state of affairs in terms of improving the situation of security. The size and role the private security industry plays in the respective national security systems of the concerned countries are extremely significant.

In the private security industry, relevant professional knowledge and skills are required so that private security personnel can effectively accomplish their roles. These skills are attained through continuous and robust professional training. As Olonisakin, Ikpe, and Badong (2009:15) argued training improves the tactical and operational competence of these agencies and then contributes to required security service. Depending on the nature of undertakings in the field of PSC, it is a must that the person has adequate practical and theoretical knowledge and psychological readiness before joining the industry. This helps the security personnel to perform their security tasks legally, ethically, and professionally and reduce the possible dangers the personnel may exhibit as a result of needless deeds. Proper and continuous professional training can increase quality services and performance; allows the security personnel to acquire sufficient knowledge and experience in the field and enables the security personnel to develops self-confidence and provide security and safety services competently (Akinade, 2019). To George (2020) security personnel training provides pertinent information that helps them to respond to incidents; gives the security personnel a better understanding of legal standards and limitations that enables them to observe their duties and rights and open access to career options in the industry. "As private security becomes more involved in public patrols, interaction with citizens, securing sensitive installations, and engaging in more frequent detentions and arrests, it becomes paramount that the industry is expected to train their security personnel in an appropriate manner" (Law Commission of Canada, 2006:103). There should be a mechanism to ensure that everyone can undergo proper security training before they are granted a license to work as a security practitioner.

Studies showed that the growth of the private security industry has brought many problems as far as entrenching peace and security is concerned. Private security compromises national and human securities. Furthermore, this industry is often criticized for its lack of institutional arrangements, lack of adequate recruitment and training standards including problems of certification and regulation of the behaviors and practices of recruits. People engage in the industry without having proper initial training and relevant experiences. The duration and content of training of the courses also vary in different countries. According to Griffiths et al., (2010), some initiatives have been taken by few countries and security companies, but the degree of enforcement is insignificant. As a result, companies, employees, clients in a particular society, in general, are not beneficiaries of these.

In Ethiopia, PSCs are now becoming an important partner that complements police efforts. At the moment, 
335 private security companies have registered and providing security services to their clients (EFPC, 2021). Researches regarding the private security service in Ethiopia have so far received very little attention. Even the existing scanty research conducted in this regard is not comprehensive and does not reflect the reality in Ethiopia. Hence, the very objective of this article is, therefore, to examine the private security in Ethiopia focusing on normative frameworks, institutional setups, and training of the private security guards that stalled it to provide effective security service to its clients. To achieve this objective, the article employed a qualitative research approach. Both primary and secondary data are consulted.

The article has five sections. The first section is introductory. Pertinent literature is briefly reviewed under section two. In the third section, the research method is conferred. The fourth section discussed with findings and discussion. In the fifth section, the conclusion and the ways forward are highlighted.

\section{Literature Review}

\subsection{Private Security: Explained}

The term private security is highly contested. As a result, numerous definitions have been used various scholars. The private security industry is made up of entities of various forms, ranging from multinational companies to individual contractors. In regulating the industry, it is left to each country to define private security providers and set out what type of entities and services are covered for its regulation. The definition hinges on the local context and the services performed within the respective country's jurisdiction (The Danish Institute for Human Rights, 2019).

Few model definitions are discussed in this article. To Shah (2016) private security means the protection of property, people, and information by the private sector without the help of the government. This includes protection in case of manmade and natural catastrophes including terrorist attacks and natural disasters. Private security refers to the individuals providing all types of security-related services, such as investigation, guard, patrol, detection, alarm, and armored transportation all aimed at crime prevention and detection the term private security mainly indicates security service provided by a person than a public servant. It protects or guard people or property or both. This includes the provision of armored car service (Anicent, 2014). Similarly Abrahamsen (2011) defines 'private security agency' means a person or body of persons, other than a government agency, department, or institutions engaged in providing private security services such as training to private security guards, or their supervisor or providing security guards to any industrial or business undertaking or a company or any other person or property.

Hence, the term private security embodies a wide array of institutions such as security guard companies and investigative services among others. The security personnel hired by these companies can be armed or unarmed, can be employed as either in-house or contract employees and can have different powers, depending on where they work and what responsibilities they fulfill. The term private security is not defined in Ethiopia.

\subsection{Institutional and Normative Frameworks vis-à-vis Private Security in Ethiopia}

The role of the FDRE Attorney General and Federal Police Commission (FPC) is pertinent as private security providers are actively engaged in one of the major policing tasks. At the federal level, the Attorney General has the power to supervise the overall activities of policing tasks including crime prevention and investigation by directing the FPC. In this regard, Attorney General may play its role in deciding who must or must not engage in the service of crime prevention as an appropriate law enforcement organ directly involved in the enforcement of the law (Federal Attorney General Establishment Proclamation No. 943/2016, Articles 5 and 6).

Under the Attorney General, the FPC is also established by law to serve the public, respect, ensures the observance of human and democratic rights, and maintains peace and welfare of the public. Among other things, the FPC is entrusted with the general objectives to maintain peace and security of the public by complying with and enforcing the Constitution and other laws of the country, and by preventing crime through the participation of the community. Further powers and functions of the FPC which has particular relevance to the context of security service are also under the Ethiopian Federal Police Commission Establishment Proclamation No. 720/2011. For instance, under its Article 6 sub Article 9 and 10 the FPC has the power and duties to safeguard institutions of the Federal government; provide security protection to higher officials of the Federal government and dignitaries and diplomats of foreign countries, and install CCTV cameras at the proper places to prevent and investigate crimes.

Under Article 7(16) of the Ethiopian Federal Police Commission Establishment Proclamation No. 313/2003, the FPC can delegate its powers and functions for law enforcement tasks to other institutions when it deems necessary. One can argue that it is in this context that the private security industry can provide security services to private institutions like banks and insurance companies, hotels, different industrial sectors, and so on. Article 6(28) of Proclamation number No.720/2011 states that the FPC issues certificates of competence to private institutions to enable them to take part in providing security service.

The FDRE National Crime Prevention Strategy (2020) has also recognized private security institutions as 
important partner in law enforcement activities. The private security institutions along with the police and community are required to perform crime prevention activities. Yet the role of these institutions in crime prevention is not indicated. Hence, the role of the private security industry is to some extent legitimized under the Ethiopian legal infrastructure. Nevertheless, nowhere is mentioned the role the security industry can play. In other ways, the roles that the FPC can delegate to these agencies are not indicated.

The FPC also prepared a working guideline through which PSCs are governed. The Guideline 01/2011, inter alia, insists that PSCs should have a training syllabus and be obliged to send their personnel for proper training. According to the guideline, PSC personnel must be accomplished 90 days of training under category I and 15 days under category II (Article-7 of Police Guideline). However, this does not amount to the existence of a national standard for the training of private security guards in the country. The Guideline also doesn't specify who (the police, the company itself, or any other institution) conducts this training. In addition, the standard curriculum and module including the contents of the training and its quality are not mentioned. As a consequence, the duration and content of training for recruits and the quality of trainers in the industry are left to the discretion and capability of various PSCs. During the preliminary observation, it was also observed that the training facilities of some companies are poor and below standard.

In the $18^{\text {th }}$ session of the United Nations Commission on Crime Prevention and Criminal Justice (UNCCPCJ), the Secretary-General requested the member states to examine the role played by private security agencies in their jurisdiction. Later in its $20^{\text {th }}$ session, an analysis of the replies provided by member states was presented to the Commission and as result, most of the states noted that the private security industries had a role in policing such as crime prevention and community safety. The states had adequate normative frameworks and institutional arrangements on private security along with adequate monitoring mechanisms. However, some of the states noted deficiencies in this regard (UNCCPCJ, 2009).

The International Code of Conduct for Private Security Service Providers (ICOC, 2013) is relevant here to mention as far as the private security service provider is concerned. The signatories to this code were private security service providers mainly UK, USA, Sweden, Canada, South Africa, and India. Neither private security industries from Ethiopia signed the code of conduct nor did the Ethiopian government still enact proclamation or regulation. The Code regulates both private security industries and private security guards operating in the country. Its preamble affirms the fact that in providing security services, the activities of private security companies can have positive and negative impacts for their clients, the local population in the area of operation, the general security environment, and the enjoyment of human rights and the rule of law.

\section{Research Method}

The study employed a qualitative research method. The qualitative approach helps to understand the real-life setting and allows the active involvement of the research participants (Creswell, 2007, p.40; Yin, 2011). As it allows for the possibility of gaining significant knowledge about the problem under investigation, this study used a case study approach (Yin, 2003). The study setting is also selected purposefully for the reason that the researcher's knowledge of the population in terms of research objectives. The researcher collects data from the respondents with better knowledge and experience about the problem (Creswell, 2007).

As a result, this study used an exploratory case study approach. As Creswell (2007) stated, the major data collection tools in a qualitative approach include an interview, observation, and document review. Hence, a case study design involves detailed, in-depth data collection tools involving multiple sources of information (2014). Both primary and secondary data sources were used to collect pertinent data. To draw adequate conclusions, the researcher used various data collection tools such as in-depth interviews of key informants, focused group discussions, direct observation as well as and document review.

As stated above, the researcher employed the purposive sampling technique to select major institutional data sources. Accordingly, lawmakers, security service providers, law enforcement organs, and private security service users are identified as the major sectors that have a direct connection to the subject under exploration. A total of 65 respondents were nominated purposefully for both interview (36) and FGD (29): 34 from Police and civilian government officials from the concerned ministries and bureaus; five representatives from the inhouse/proprietary security institutions; 18 from private security companies and eight from service recipients.

\section{Result and Analysis}

Professionalism is an important element in the provision of private security services and hence any securityrelated tasks must be undertaken with the necessary security knowledge, skill, and competency. In defining the professionalism of private security, a code of ethics, security experiences, proper education, and training are needed (Fischer et al, 2008). This means that security personnel needs to receive proper training regarding their duties as well as ethical standards and professional conduct in addition to those developed by the companies. Being a security professional means displaying competence in one's area of expertise and striving to demonstrate the core values and competence of the professional (Lawrence, 2017). As ISS (2017) states, "a security guard is 
professional and ethical if he/she does what is considered to be morally sound and acts in a manner one would expect him/her" (para,2). Today, private security is moving towards professionalism and several efforts have been made by the participants of the industry.

Despite some efforts to professionalize the PSC, there are major obstacles that need to be overcome. One such problem is the training and education of security guards. Many of these guards are poorly paid and undertrained. Some minimal standards exist in different places, however, there is unwillingness by countries and companies to educate and train these personnel adequately. Considering the importance of private security personnel in the crime prevention effort, it is expected to provide them with a minimum standard of training. However, this is not the case since most of these personnel are received so little training when compared with their public-sector counterparts (Inter-State Security, 2017).

As confirmed by the respondents, the Ethiopian Private Security Industry (EPSI) lacks professionalism. For example, one of the police interviewee stated that currently any person who has a degree or diploma can register and get a license for establishing a security firm and practice security-related tasks. He added that there is a common practice of recruiting incompetent individuals who perform specialized tasks that require special skills and training. Another police interviewee stated that most of the private security guards in Ethiopia have a very low educational background. This is because the job is regarded as a low-level job and it doesn't require any profession or skill except physical fitness. According to most FGD respondents and key informants, the majority of the people in the industry are less educated whose training is limited to primary school or less. Today, the sector accommodates everyone since the country is characterized by high unemployment rates and has left job seekers to look for any employment that would bring income for the sustenance of the household.

As noted above, lack of adequate training is one of the challenges that the PSC industry in Ethiopia faces. Currently, many PSCs are operating in Ethiopia having a big size of personnel. Despite this big size, there are no specific standards and policies that govern the training activities of the companies as well as their personnel. As one of the private security company owner replied, the quality and content of training offered by these companies differ significantly from one to the other. This is also confirmed by one of the police interviewee, most PSCs in Ethiopia offer some security-related courses for their personnel, but many PSCs deploy security personnel to duty without any knowledge or with little know-how about security issues. As the FGD discussants replied, this problem is mainly the concern of unregistered PSCs but yet several registered big security firms also show little interest to embark on periodic training of their personnel. They further claims that this problem has contributed to the incompetence, lack of professionalism, and inefficiency characterizing many private security personnel in Ethiopia.

Under the existing system, the FPC is a responsible organ for the issuance of a license for the private security companies in Ethiopia. The FPC issued a working guideline through which PSCs are governed. The guideline 01/2011 insists that PSCs should have a training syllabus and be obliged to send their personnel for proper training. According to the guideline, PSC personnel must be accomplished 90 days of training under category I and 15 days under category II (Article-7 of Police Guideline). However, this does not amount to the existence of a national standard for the training of private security guards in the country. The Guideline also doesn't specify who (the police, the company itself, or any other institution) conducts this training. In addition, what is to be provided (contents, quality of training, any standard curriculum and modules) is not mentioned. As a consequence, the duration and content of training for recruits and the quality of trainers in the industry are left to the discretion and capability of various PSCs. During the fieldwork, it was also observed that the training facilities of some companies are poor and below standard.

Due to the aforesaid problem, each PSC has adopted its ways and procedures of training for its personnel. Currently, PSCs have failed to coordinate their efforts and to harmonize the content of the training they provide. As most of the respondents described, this is due to the failure to have a comprehensive and unified standard of training for PSCs. Since each PSC administers its training, the quality of security service varies. As a result, no one is sure that whether the security personnel undergo rigorous training periodically. While the FPC has duty bound to inspect the training, it does not engage in this properly. The Police Guideline 01/2011 mandates security guard certification but the actual practice shows that no one abides by this rule. As one of the police interviewee revealed, each PSC offers training with diverse training methodologies and philosophies and this resulted the personnel to engage in private security service without acquiring common techniques, ethics, knowledge, and skill.

As one of the police interviewee stated, many security companies have designed below eight hours training packages for their security personnel and this training are provided by way of orientation. In most cases, on-thejob training is rare and security personnel go without adequate information about their engagement in the industry. In similar way, the focus group discussants reported that several PSCs recruit staff with questionable backgrounds. For them, many of this security personnel lack training, license, and are deployed for security work without proper background checks.

According to police officials and industry experts, several security companies are investing little or nothing 
in training their employees. Many of these companies are shaping their subjects and courses in line with the owner's interest and these courses are mostly given either by employers themselves or lower-level staff such as supervisors. In this case, the quality of instruction is questionable since these people do not have the required knowledge and skill in the area. As one of the police interviewee stated, these situations allow non-experienced security practitioners to enter the industry. One of the private security company owner described that his company employed several personnel for the last five years. However, these often "appear unprofessional since they lack the requisite skills and knowledge both at individual and the institutional levels". This lack of standard training does not adequately prepare PSC employees to competently engage in providing private security service. Their training does not capacitate PSC personnel to respond to more complex tasks and emerging security threats such as organized crimes and terrorism. It also makes them vulnerable to manipulation "as they have no bargaining power for higher salaries or better working conditions nor are they aware of their labor rights" (Vinko, 2013, p.11).

Today criminals make the task of security providers very tough because of the emergence and use of advanced technologies. To counter this, security providers and their personnel must go for proper training and make sure that they have the necessary knowledge, skills, and experiences. The quality and skills of security personnel have a positive impact and influence on the quality of security provision. In circumstances where proper training and license are absent by the security personnel, there will be a low standard of professional practices. In this respect, Akinade (2019:4) argued that

the standard of the profession will suffer because of a lack of relevant experience by the guards engaged in security practice. The lack of experience can lead to the occurrence of clumsy and substandard performance which could result in serious mistakes and inadequate professional practice. It can also cause reduced self-confidence, which in turn decreases motivation and morale.

According to Inter-State Security (ISS) (2017), the development of specialized skills and training, are very crucial for the development of professionalism. It is, therefore, important for the companies to ensure that security employees should have all of the basic training that qualifies them to serve as professional private security officers. It is also essential for the state to introduce some changes in the area of training requirements for all security practitioners before licensing them. For Akinade (2019), this move aims to improve the profession, knowledge, and skill of individual security personnel thereby increasing the level of satisfaction both by the security provider and the user on safety matters. The presence of a high commitment to professional value and occupational integrity is an essential component for the true test of professionalism in the security industry. So, companies and their personnel must adhere to a professional code of ethics. Even without considering the government's frameworks, PSCs and security practitioners can set some standards to increase their professionalism in the industry.

Regarding the institutional framework, Hans (2007) explained that in some countries the issue of training is regulated by the ministries of the interior like the case in Spain. Others recommend that companies can handle this and the training given by them is sufficient (Italy). Some other countries prefer an autonomous body for handling the case. In South Africa, different security institutions that are recognized by the Private Security Industry Regulatory Authority (PSIRA) provide training for PSC personnel. In Kenya, the Private Security Training Academy (PSTA) is responsible for the provision of security training (Usalama Reforms Forum, 2019). Interviewed PSC managers and police officers recognized an enhanced training package as the most significant part of the industry. Most of these respondents had the opinion that there should be certified training centers and approved courses for the PSC personnel to harmonize and raise standards. This strongly suggests that adequate and proper training should be provided by an autonomous institution, possibly by the certified and wellrecognized institution rather than by PSCs themselves. However, there are no such systems and models in Ethiopia.

To qualify for the work, PSCs' personnel must undergo meaningful training and enhance their professional development. In this regard, standardization of training before assignment, and on-the-job training are of paramount importance. According to UNODC (2014), several issues need to be considered by the state when dealing with the training standards of civilian private security providers. The identification of contents of basic training, mandatory numbers of hours, and the types of refresher courses are very important and must be recognized. This enables states to pass the best decision on the issue and to create an effective training regime.

As could be understood from the foregoing, the nature of PSC services entails front-line practitioners who have some knowledge and skill in the subject area. In this respect, UNODC (2014) suggests that PSCs' personnel must cover the following basic courses before their deployment:

role of civilian private security services and their contribution to crime prevention and community safety; relevant legislation relating to and regulating powers of arrest and the use of force; communication skills relating to oral and written reports; code of conduct and professional ethics; customer and client handling skills; emergency procedures for natural disasters, accidents, and other emergencies; human rights and adherence to applicable national and international human rights 
standards and norms; if applicable use of firearms (when, how, limitations); and use of security equipment and devices such as security alarms, screening equipment, and radio (p.65).

Though it varies greatly from country to country, there should be also a minimum number of hours for training. In the USA, the states are responsible for formulating training standards and the compulsory training hours for security personnel vary from eight hours in Washington to 40 hours in California. In Europe, the standard is different from country to country. For instance, "a security guard needs $320 \mathrm{hrs}$ of training in Hungary, $288 \mathrm{hrs}$ in Sweden, 180hrs in Spain, 127hrs in Belgium, 70hrs in France, 40hrs in Bulgaria and Germany" (p.72). When looking at the African experience, security personnel go for 15 to 30 days in Kenya and two weeks in Tanzania, to mention some. Compared to other countries' experiences, a-90-day training in Ethiopia is too long and thus needs some adjustment.

Similarly, it is very important to reiterate here that private security personnel should have the latest knowledge and skills. To enhance service efficiency and maximize outputs, periodical upgrade of employees' skills is paramount. One such method is on-the-job training. This method can improve the skills and knowledge of the security personnel and increases their level of performance. In this respect, Button (2012) provides different models that can be applied by states: In South Korea, for example, the law obliges each security personnel to take monthly refresher training in different topics and subjects. In Belgium, there are compulsory refresher courses associated with the law and security matters every five years. These courses are lasting for eight hours. Similarly, guards must go for two days refresher course every year in the United Arab Emirates. Moreover, states must create training standards for the level of expertise since it requires additional knowledge and skill. Examples include critical infrastructure security, crowd management, VIP protection, and cash transport security. However, one thing that must be noted here is that states must ensure that all security personnel including supervisors and managers should go through and accomplish the course as a part of the requirement for licensing. This helps them to have similar operational security know-how as the frontline security workers and for the proper management of their subordinates.

From the overall analysis of this study, private security in Ethiopia is facing many challenges vis-à-vis training, normative frameworks, and institutional setup and professionalism. These absences of standards pose major challenges to PSCs and their personnel. These challenges tend to drastically reduce capacity in the effort of effectively providing essential services for meeting the security needs of clients. It is also curtails the bargaining capacity of the security personnel while exercising their right. Hence, it needs to develop feasible policies and strategic options that could meet international standards as well as clients' expectations.

\section{Conclusion and the Ways Forward}

The study unveiled that lack of legal and policy frameworks, lack of standardized training and regular supervision, and lack of coordinated training between the private security agencies and the police are among the major challenges that hinder effective security service to clients. The study uncovered that PSCs and their personnel lack professionalism in the areas of security. Currently, there is no comprehensive law and standard that facilitates the training of security personnel in Ethiopia. There are different methods and curricula offered to PSC staff. However, these do not adequately prepare PSC employees to discharge the expected duties and drastically reduced their capacities to effectively provide essential services for the security needs of their clients.

The study further identified that there is no independent institution that provides training targeting PSCs' personnel. At the moment, the provision of training is haphazardly undertaken by each private security agency. However, it is suggested that adequate and standard training should be provided by an autonomous institution, possibly by the certified and recognized agency rather than by private security companies themselves.

As the finding revealed given the role that the private security sector is playing and can play in improving the overall security situations in Ethiopia, it is important to develop feasible policies and strategic options that could address recurrent problems. In this respect, the existence of training standards and requirements at the national, local, industry associations, and individual industry levels are highly recommended. Furthermore, it is essential to take the appropriate steps to ensure that the activities of PSCs conform to the national standards and policy as well as internationally recognized standards and best practices.

\section{References}

Admin ASTM (2017). Importance of Security Guard Training. Accessed on April 52021 from http://astm.co.in/astm-blog/importances-of-security-guard-training/.

Akinade BA. (2019). Training, Education and Manpower Development for Security Personnel: Relevance and Perspective in Nigeria. Social Int J.; 3(1), pp. 8, 50-55. DOI: 10.15406/sij.2019.03.00153.

Anicent, T.(2014). The Role of Private Security In Community Policing: Case Of Kikuyu Sub County, Kiambu County, Kenya. University of Nairobi Department of Sociology And Social Work

Button, M. (2012). Optimising security through effective regulation: lessons from around the globe. In T. Prenzler (Ed.), Policing and security in practice: challenges and achievements (pp. 204-220). (Crime 
prevention and security management series). Palgrave Macmillan.

CoESS \& Uni Europa (2003). "Code of Conduct and Ethics for the Private Security Sector”.Availableonline:www.coess.org/documents/code_of_conduct.pdf.(accessed 28/5/2018).

Creswell, J. W. (2007). Qualitative inquiry and research design: Choosing among five approaches (2 ${ }^{\text {nd }}$ Ed.). California: Sage.

Creswell, J. W. (2014). Qualitative, quantitative, and mixed methods approach ( $4^{\text {th }}$ ed.).Sage.

Ethiopian Federal Police Commission [EFPC] (2018). Report on private security companies: Fiscal year 2021.

Ethiopian Federal Police Commission [EFPC] (2011). Guideline No. 01/2011 of 2011, Private Security Companies Registration and Licensing, Addis Ababa.

Ethiopian Federal Police Commission Establishment Proclamation No.313/2003 of Federal Democratic Republic of Ethiopian Negarit Gazeta 9th year No.30

Fischer, R., Halibozek, E., \& Green, G. (2008). Introduction to Security. Sheridan Books.

George Kozhar (2020). Five Benefits of Professional Security Guard Training. Accessed on 21 March 2021, from https://www.issinvestigation.com/blog/security-guard-training-nyc/.

Griffiths; M., Brooks, D. J. \& Jeffrey C. (2010). Defining the Security Professional: Definition through a Body of Knowledge. p.47. Edith Cowan University. DOI:10.4225/75/579ed9e4099cd.

Hans, B., Caparini, M. \& Eden C. (2007). Regulating Private Security in Europe: Status and Prospects, DCAF, Policy Paper - №20, pp.25-29.

Inter-State Security (2017). Ethics and Professional Conduct of Security Guards. Available at https://www.interstatesecuritycorp.com/ethics-professional-conduct-security-guards/ accessed on 9/6/2019.

John F. Lemon (2018). Private Security Officer Basic Training Program, South 400 East, Heber City, Utah 84032.

Law Commission of Canada (2006). In Search of Security: The Future of Policing in Canada. Ottawa, Ontario, p.103. ISBN: JL2-26/2006E Catalogue: 0-662-42902-8.

Lawrence J. F. (2016). Importance of Security Guard Training (par.1) accessed on May 23,_2021 from http://eosacademy.com/

Lawrence J. F. (2017). Physical Security: 150 Things You Should Know (2 ${ }^{\text {nd }}$ ed.).

Olonisakin, F., Ikpe, E. \& Badong, P. (2009). The Future of Security and Justice for the Poor: A "Blue Sky" Think-Piece. CSDG Policy Study 21, Conflict, Security and Development Group. London: King's College.

Proclamation to provide for the establishment of the Ethiopian Federal Police Commission, Proclamation Number 720/2011, Federal Negarit Gazette, No.2 (November 28 ), Addis Ababa, Ethiopia: Birhanena Selam Printing Press.

Shah,K.(2016). Private Security Services Industry: The Challenges Ahead. International Research Journal of Management Sociology \& Humanity (IRJMSH ).

Security Professionals' Taskforce (2008). Outcomes of the 2008 Security Professionals' Congress. In Simonsen, E. (1996). The case for Security Management is a Profession. International Journal of Risk, Security, and Crime Prevention, 1(3), 229-232.

United Nations Office of Drugs and Crime [UNODC] (2014). State Regulation Concerning Civilian Private Security Services and their Contribution to Crime Prevention and Community Safety. Vienna, pp. 21-64.

Usalama Reforms Forum (2019). Baseline Study on the Private Security Industry in Kenya: challenges and implementation of the new regulatory framework, p.43.

Yin, R., K. (2003). Case study research design and methods applied social research method series ( ${ }^{\text {rd }}$ ed.). USA: Sage.

Yin, R., K. (2011). A qualitative study from start to finish. New York. The Guilford Press. 